Article

\title{
Falling behind the Rest? China and the Gender Gap Index
}

\author{
Binli Chen ${ }^{1}$ and Hailan $\mathrm{He}^{2, *}$ \\ ${ }^{1}$ School of Social Development and Public Policy, Beijing Normal University, 100875 Beijing, China; \\ E-Mail: blichen@bnu.edu.cn \\ ${ }^{2}$ Collaborative Innovation Center of Assessment for Basic Education Quality, Beijing Normal University, 100875 Beijing, \\ China; E-Mail: he.h@bnu.edu.cn \\ * Corresponding author
}

Submitted: 16 January 2020 | Accepted: 6 March 2020 | Published: 28 April 2020

\begin{abstract}
China's rank falling in the Global Gender Gap Index of the World Economic Forum has aroused the domestic scholar's controversy. Based on the data provided by the Global Gender Gap Report, this article will describe the gender inequality in China by comparing its overall index scores and scores in the fields of economic participation and opportunity, educational attainment, health and survival, and political empowerment with other countries, and then examining the reasons for China's falling in rank through the score changes of sub-dimensions and indicators. Analysis of the data suggests that China has not kept up with the rate of improvement in the overall index, and in the four fields, compared to the original 112 countries, the upper-middle income countries, and the Asian and Pacific countries. Over the 13 years covered by the report, China's score experienced a rapid improvement from 2006 to 2009 and a decline after 2013. China's high sex ratio at birth, further expansion of gender inequality in active life expectancy, and an enlarged gender gap in secondary education caused China's lagging overall score and ranking. In addition, the inclusion of measures such as secondary education enrollment, political empowerment, and other indicators also led to the backward ranking of China to some extent.
\end{abstract}

\section{Keywords}

China; gender gap; gender inequality

\section{Issue}

This article is part of the issue "Left Behind? Women's Status in Contemporary China" edited by Robert Walker (Beijing Normal University, China) and Jane Millar (University of Bath, UK).

(C) 2020 by the authors; licensee Cogitatio (Lisbon, Portugal). This article is licensed under a Creative Commons Attribution 4.0 International License (CC BY).

\section{Introduction}

Gender inequality is a basic dimension of social inequality, which is related to the development opportunities and well-being of women and men in society. In order to measure the gender gap around the world, the international community has opened up multiple indicator systems, including the Gender Development Index, the Gender Empowerment Measure, the Gender Inequality Index (GII), the UNESCO's Gender Parity Index, and the World Economic Forum's (WEF) Global Gender Gap Report (GGGR). Among such index systems, the Global Gender Gap Index (GGGI) from the WEF has had the most significant impact. In order to capture the magnitude of gender-based disparities and tracking their progress over time, the GGGI comprehensively and systematically evaluates the gender gap in the fields of economic participation, educational attainment, health and survival, and political empowerment of participating countries. The GGGR has thus become the main source of information reflecting the gender inequality around the world.

After the release of the GGGR in 2018, China's ranking dropped from 63 in 2006 to 103, which caused great controversy in China. Chinese scholars' arguments on China's ranking mainly include two aspects: First, it was argued that the indicators are unreasonable and some data sources have not been updated in time (Tang, 2019; Yang, 2018; Zheng, 2019). Secondly, it was also suggested 
that it is too simple to directly compare the data of 2006 and 2018, because the countries participating in the assessment in 2006 and 2018 are different (Tang, 2019). The GGGR reflects the gender equality of a country through two indicators - the score and ranking. The former reflects the absolute level of gender inequality in a country: The higher the score, which ranges from 0 through 1, the smaller the remaining gender gap. The latter is a relative indicator. In comparison, the ranking is more likely to be influenced by the number of participating countries. This article will focus on the question of why China's ranking on the world's foremost indicator of gender inequality has fallen markedly, from 63 to 103 between 2006 and 2018. How to understand the trend in the overall GGGI for China during this period and which factors directly lead to these changes will be discussed in this article.

In order to take account of the fact that the countries participating in the assessment in 2006 and 2018 are not the same, this study will take the 112 countries (including China) participating in the assessment in both years as a sample to study the relative position of China's gender gap. Accordingly, using the data from the 112 original countries provided in the GGGR 2006 and 2018, this study mainly focuses on descriptive statistics, reviews the changes of China's scores and rankings in overall and each field according to each indicator, and compares them with the world average (the average level of 112 original countries), countries at the same level of development (upper-middle income countries), and Asian and the Pacific countries. Based on the comparison, this article will make a more comprehensive judgment on the situation of gender inequality in China. In this process, the researchers will combine the relevant research and data released by the Chinese government to confirm or question the conclusions based on GGGR data. The data sources of this study mainly include The Global Gender Gap Report (2006-2018) published on the website of the WEF. The final part of this article reflects on the selection of the indicators used in the GGGI, in combination with the factors that lead to China's backward ranking.

\section{China's Overall Index}

China's gender gap index experienced a great change from 2006 to 2018-its overall score increased from 0.656 in 2006 to 0.673 in 2018 with rank falling from 63 to
103. Among the 112 original countries, China ranked 82 in 2018, with a fall of 19 places. The increasing score indicated that China's overall gender inequality has slightly improved, but the falling rank indicated that its speed of improvement was slower than the world average. From 2006 to 2018, the overall score in 112 countries improved by 0.040 , an increase of $6.0 \%$; China grew by 0.017 , an increase of $2.6 \%$. Over the same period, the index for upper-middle income countries, of which China is one, rose by 0.040 , an increase of $6.0 \%$, while that for Asian and the Pacific countries increased by an average of 0.034 , an increase of $5.0 \%$ (see Table 1 ). At the same time, China's gender gap index in 2018 was below than 0.677 , the average level of the new added 37 countries.

In terms of China's change trajectory (as shown in Figure 1), an initial rapid reduction in the gender gap was followed by a slow increase. During 2006-2009, China's overall score increased rapidly by 0.035 (5.3\%), while the average score for the other 112 countries participating in the assessment over the same period rose by 0.017 (2.6\%). The year 2013 was an important turning point. From 2013 to 2018, China's score decreased by $0.018(2.6 \%)$ while that for the original countries participating in the assessment increased by 0.023 (3.4\%). China's score was basically equal to that of the 112 original countries in 2013 but by 2018 had fallen to just $95.8 \%$ of the average level of those original countries.

\section{China's Performance on the Four Sub-Indexes}

There are four subfields to the index: economic participation and opportunity; educational attainment; health and survival; and political empowerment. In the four fields, the difference in educational attainment and economic participation and opportunity between China and 112 original countries was not significant in 2018 , while the difference in health and survival and political empowerment was large. China's score in health and survival was $93.9 \%$ of the average level and $74.5 \%$ in political empowerment.

During 2006-2018, China's scores for economic participation and opportunity fluctuated rapidly. In general, the index increased by 0.032 (5.2\%), which was less than for the 112 countries (0.052), and for upper-middle income countries (0.061; see Table 2). China ranked 53 in 2006, 86 out of 149 countries, and 67 out of the 112 original countries in 2018, with a drop of 14 places. The

Table 1. Comparison of overall scores between China and other countries.

\begin{tabular}{lcccc}
\hline & 2006 & 2018 & Change & Rate of change (\%) \\
\hline China & 0.656 & 0.673 & 0.017 & 2.6 \\
The 112 original countries & 0.662 & 0.702 & 0.040 & 6.0 \\
The upper-middle income countries & 0.664 & 0.704 & 0.040 & 6.0 \\
Asian and the Pacific countries & 0.674 & 0.708 & 0.034 & 5.0 \\
37 countries added after 2006 & - & 0.677 & - & - \\
\hline
\end{tabular}

Source: WEF (2006, 2018). 


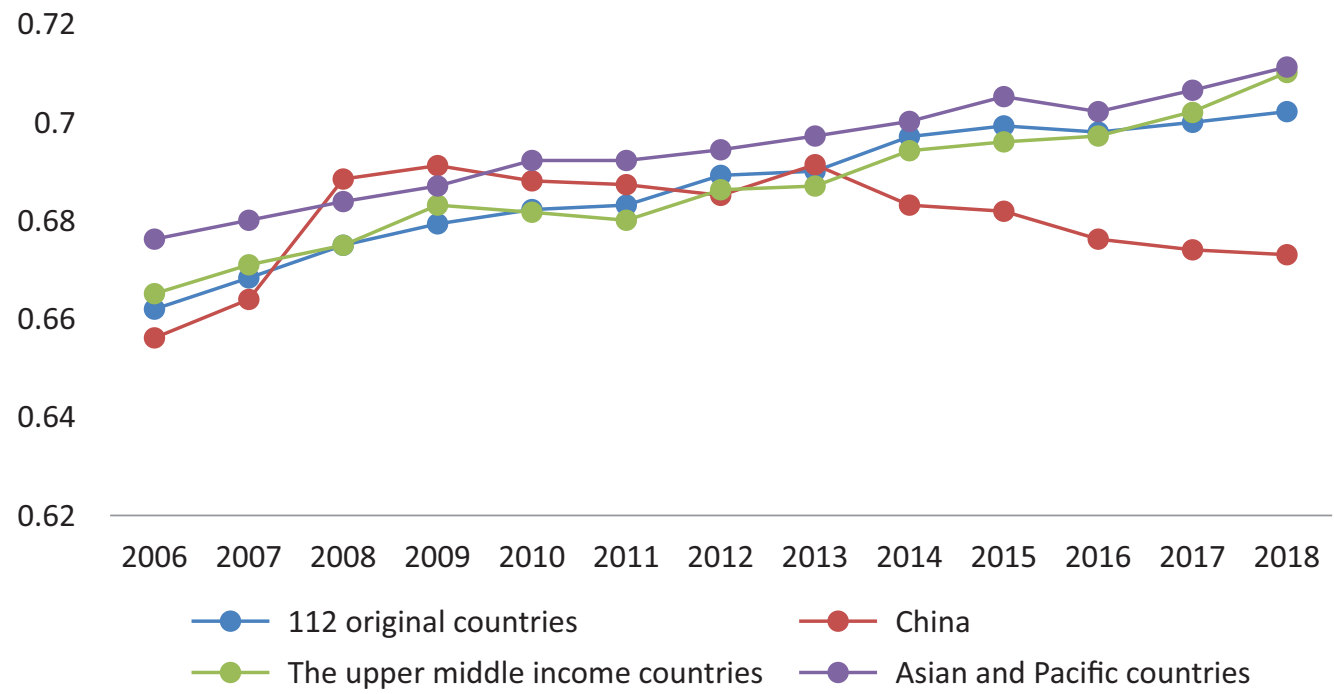

Figure 1. Time series comparison of GGGI. Source: $\operatorname{WEF}(2006,2008-2018)$.

change trajectory in this field was similar to the overall score (see Figure 2). From 2006 to 2009, the gender inequality in this field improved rapidly, with a score increase of 0.075 (12.1\%), then came to decline after 2009, with a decrease of 0.043 points or $6.2 \%$ until 2018. In 2009, China scored 1.11 times the average of the 112 original countries, and in 2015, whereas China's score had fallen to the average level of those original countries.

In 2018, the overall inequality in educational attainment in China was slightly higher than the average. During 2006-2018, the improvement in gender inequality in China's education field was not significant, with an increase of just 0.001 (0.1\%). In 2006, in terms of the gender gap of educational attainment, China ranked 78, 111 out of 149 countries in 2018 and 88 out of the 112 original countries, a decline of 10 places. During the same period, the average index scores for educational attainment for the 112 original countries, the upper-middle income countries, and Asian and the Pacific countries increased by $0.025(2.7 \%), 0.009(0.9 \%)$, and $0.023(2.4 \%)$ respectively. In contrast, China's improvement was much slower than the world average and the countries with the same development level. In terms of trend, China's index for educational attainment also mirrored its over-

Table 2. Comparison of the scores of China and other countries in four sub-indexes.

\begin{tabular}{llcccc}
\hline & & 2006 & 2018 & Change & Rate of change (\%) \\
\hline Economic participation & China & 0.621 & 0.653 & 0.032 & 5.2 \\
and opportunity & The 112 original countries & 0.598 & 0.650 & 0.052 & 8.7 \\
& The upper-middle income countries & 0.593 & 0.654 & 0.061 & 10.3 \\
& Asian and the Pacific countries & 0.664 & 0.699 & 0.035 & 5.3 \\
& 37 countries added after 2006 & - & 0.649 & - & - \\
Educational attainment & China & 0.957 & 0.958 & 0.001 & 0.1 \\
& The 112 original countries & 0.940 & 0.965 & 0.025 & 2.7 \\
& The upper-middle income countries & 0.973 & 0.982 & 0.009 & 0.9 \\
& Asian and the Pacific countries & 0.961 & 0.984 & 0.023 & 2.4 \\
Health and survival & The 37 countries added after 2006 & - & 0.935 & - & - \\
& China & 0.936 & 0.915 & -0.021 & -2.2 \\
& The 112 original countries & 0.973 & 0.973 & 0 & 0 \\
& The upper-middle income countries & 0.972 & 0.975 & 0.003 & 0.3 \\
& Asian and the Pacific countries & 0.971 & 0.969 & -0.002 & -0.2 \\
& 37 countries added after 2006 & - & 0.971 & - & - \\
Political empowerment & China & 0.111 & 0.164 & 0.053 & 47.7 \\
& The 112 original countries & 0.140 & 0.219 & 0.079 & 56.4 \\
& The upper-middle income countries & 0.127 & 0.206 & 0.079 & 62.2
\end{tabular}




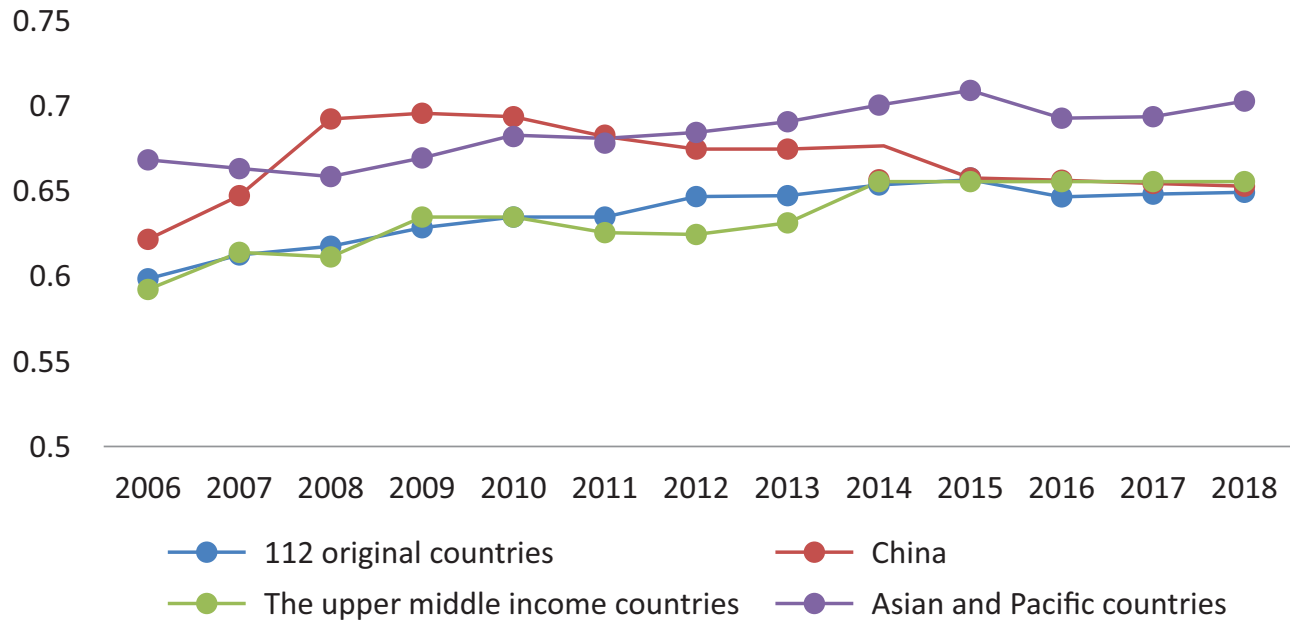

Figure 2. Time series comparison of economic participation and opportunities. Source: WEF (2006, 2008-2018).

all score, with rapid growth of 0.023 (2.4\%) from 2006 to 2008, while the average increase for the other 112 countries during the same period was $0.008(0.9 \%)$. From 2009 to 2015, China's score for gender equality in educational attainment was far higher than the average, but it started to decrease markedly from 2016, falling by 0.03 points (3\%) by 2018 (as shown in Figure 3).

Health and survival was the only field in which China's gender gap increased almost continuously between 2006 and 2018, with its score correspondingly decreasing by 0.021 . Over the same period, the average score of 112 countries and the upper-middle income countries increased but only slightly. Moreover, the score for the Asian and Pacific countries also decreased but less so (0.002), suggesting that this pattern might be partly related to cultural factors. In terms of the change trajectory, China's score fell rapidly between 2009 and 2010 and after 2014. By 2018, it was the last of all countries on this component of the overall index.

In the framework of gender inequality constructed by GGGR, China's gender gap with respect to political empowerment showed the greatest improvement. That said, according to the data provided by GGGR, gender inequality in political empowerment was higher than the average for all countries and for those at the same income level. During 2006-2018, the index score for China increased by $0.053(47.7 \%)$, while that for the 112 original countries increased by an average of $0.079(56.7 \%)$ and that for the upper-middle income countries increased by $0.079(62.7 \%)$; China's improvement was much slower than the world average and the countries with the same development level.

China's gender gap in economic participation, educational attainment, and political empowerment was smaller than the 37 new added countries. However, the gender gap in health and survival was enlarged which led to backward ranking of China.

\section{Index of Indicators in the Four Fields}

\subsection{Economic Participation and Opportunity}

Female participation in the labor force in China was much above average in 2006 (see Table 3). However, during the period 2006-2018, China's gender gap relating to labor force participation increased rather than narrow-

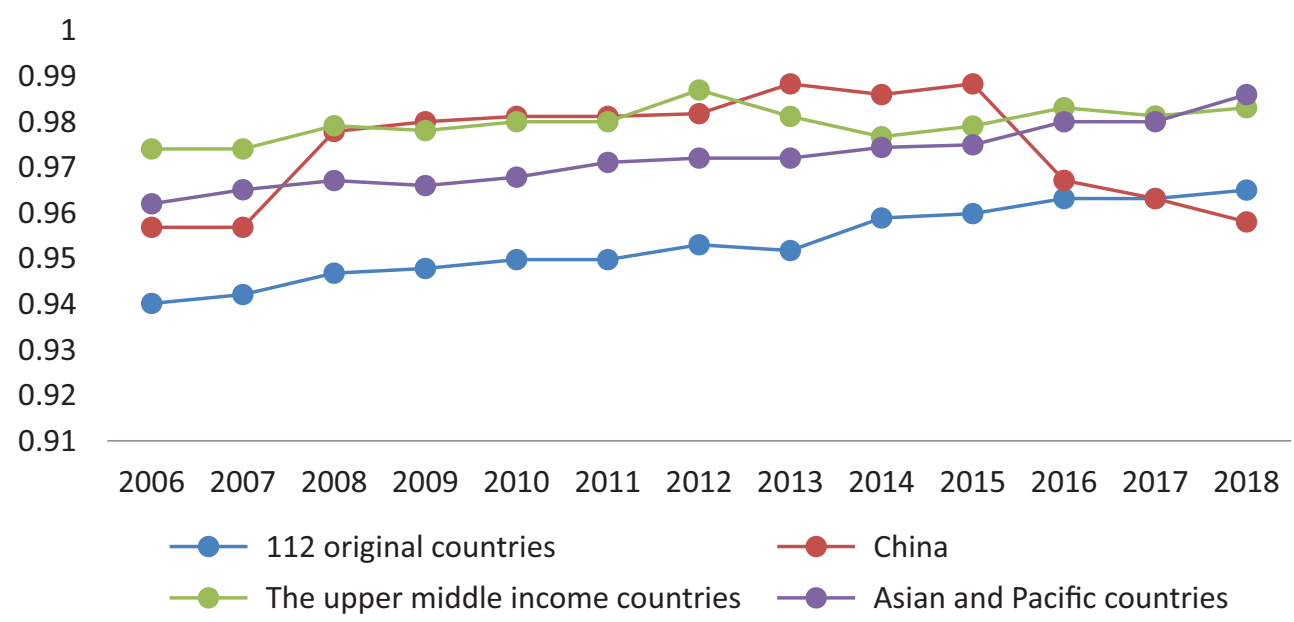

Figure 3. Time series comparison of educational attainment. Source: WEF $(2006,2008-2018)$. 
Table 3. Comparison of the scores of China and other countries in economic participation and opportunity.

\begin{tabular}{|c|c|c|c|c|c|}
\hline \multicolumn{2}{|c|}{ Economic participation and opportunity } & \multirow{2}{*}{$\begin{array}{l}2006 \\
0.84\end{array}$} & \multirow{2}{*}{$\begin{array}{r}2018 \\
0.831\end{array}$} & \multirow{2}{*}{$\begin{array}{l}\text { Change } \\
-0.009\end{array}$} & \multirow{2}{*}{$\frac{\text { Rate of change (\%) }}{-1.1}$} \\
\hline Labor participation & China & & & & \\
\hline & The 112 original countries & 0.685 & 0.748 & 0.063 & 9.2 \\
\hline & The upper-middle income countries & 0.670 & 0.722 & 0.052 & 7.8 \\
\hline & Asian and the Pacific countries & 0.74 & 0.791 & 0.051 & 6.9 \\
\hline \multirow[t]{4}{*}{ Wage equality for similar work } & China & 0.61 & 0.643 & 0.033 & 5.4 \\
\hline & The 112 original countries & 0.637 & 0.640 & 0.003 & 0.5 \\
\hline & The upper-middle income countries & 0.630 & 0.617 & -0.013 & -2.1 \\
\hline & Asian and the Pacific countries & 0.708 & 0.709 & 0.001 & 0.1 \\
\hline \multirow[t]{4}{*}{ Estimated earned income } & China & 0.66 & 0.621 & -0.039 & -5.9 \\
\hline & The 112 original countries & 0.528 & 0.588 & 0.060 & 11.4 \\
\hline & The upper-middle income countries & 0.472 & 0.601 & 0.129 & 27.3 \\
\hline & Asian and the Pacific countries & 0.593 & 0.638 & 0.045 & 7.6 \\
\hline \multirow{4}{*}{$\begin{array}{l}\text { Legislators, senior officials, } \\
\text { and managers }\end{array}$} & China & 0.14 & 0.201 & 0.061 & 43.6 \\
\hline & The 112 original countries & 0.359 & 0.469 & 0.110 & 30.6 \\
\hline & The upper-middle income countries & 0.366 & 0.497 & 0.131 & 35.8 \\
\hline & Asian and the Pacific countries & 0.352 & 0.466 & 0.114 & 32.4 \\
\hline \multirow{4}{*}{$\begin{array}{l}\text { Professional and technical } \\
\text { workers }\end{array}$} & China & 0.81 & 1.00 & 0.190 & 23.5 \\
\hline & 112 original countries & 0.794 & 0.867 & 0.073 & 9.2 \\
\hline & The upper-middle income countries & 0.848 & 0.953 & 0.105 & 12.4 \\
\hline & Asian and the Pacific countries & 0.834 & 0.918 & 0.084 & 10.1 \\
\hline
\end{tabular}

ing, as indicated by a $1.1 \%$ fall in the index, while the two indicators of the remuneration gap take on different trends. The improvement in wage equality for similar work was much greater than elsewhere although even by 2018 China had not caught up with other countries in Asia. However, the gap in estimated earned income in China which in 2006 was much narrower than average subsequently expanded during this period, with the score decreasing by 0.039 (5.9\%), while that of other countries rose causing China's ranking to drop from 19 in 2006 to 73 out of 149 countries in 2018. Among the 112 countries, it ranked 58 in 2018. During the same period, the score for the 112 original countries increased by $0.060(11.4 \%)$, that of the upper-middle income countries by $0.129(27.3 \%)$, and Asian and the Pacific countries by 0.045 (7.6\%). Although women's participation rate in the labor market remains relatively high, the gap between women and the men's wage in the labor market has widened, a finding confirmed by other research examining the effects of the economic transformation ( $\mathrm{Li}$ \& Li, 2008).

The two indicators intended to capture the advancement gap, the percentage of, first, legislators, senior officials, and managers and, secondly, the percentage of professional and technical workers who are women, have both improved in China. In detail, the greatest improvement occurred with respect to professional and technical workers, with an increase in the index of 0.190 (23.5\%), compared to smaller increased for the original 112 countries, the upper-middle income countries, and the Asian and the Pacific countries, namely 0.073 (9.2\%), 0.105
(12.4\%), and 0.084 (10.1\%) respectively. In this regard, China has achieved gender equality, which could be attributed to the rapid expansion of higher education in China. However, in contrast, women in China are likely to face higher barriers than those in other countries in acquiring positions as legislators, senior officials, and managers. In 2018, China scored 0.201 on this criterion and, although the score increased by 0.061 (43.6\%) between 2006 and 2018, China still lags behind the world average level and that of countries the same level of development (as shown in Figure 4).

There is a basic contradiction in the gender gap in the economic field, that is, on the one hand, the rapid reduction in gender inequality in the field of education leading to improvement of women's education level provide human capital sufficient for women to enter high-income industries; on the other hand, a rising income gap between different genders for similar work, and women's access to managerial opportunities in the labor market remaining low. The underlying reason may be increased occupational gender segregation in the labor market since the economic transformation (Deng \& Ding, 2012; Wu $\& W u, 2009)$. The existing research finds that the higher the degree of marketization, the greater the impact of occupational gender segregation, and the higher the degree of occupational segregation, the greater the gender income gap (He \& Wu, 2017). Occupational gender segregation is essentially a kind of structural discrimination against women in the labor market, which can be divided into horizontal occupational segregation and vertical position segregation (Anker, 1997; Tong \& Wang, 


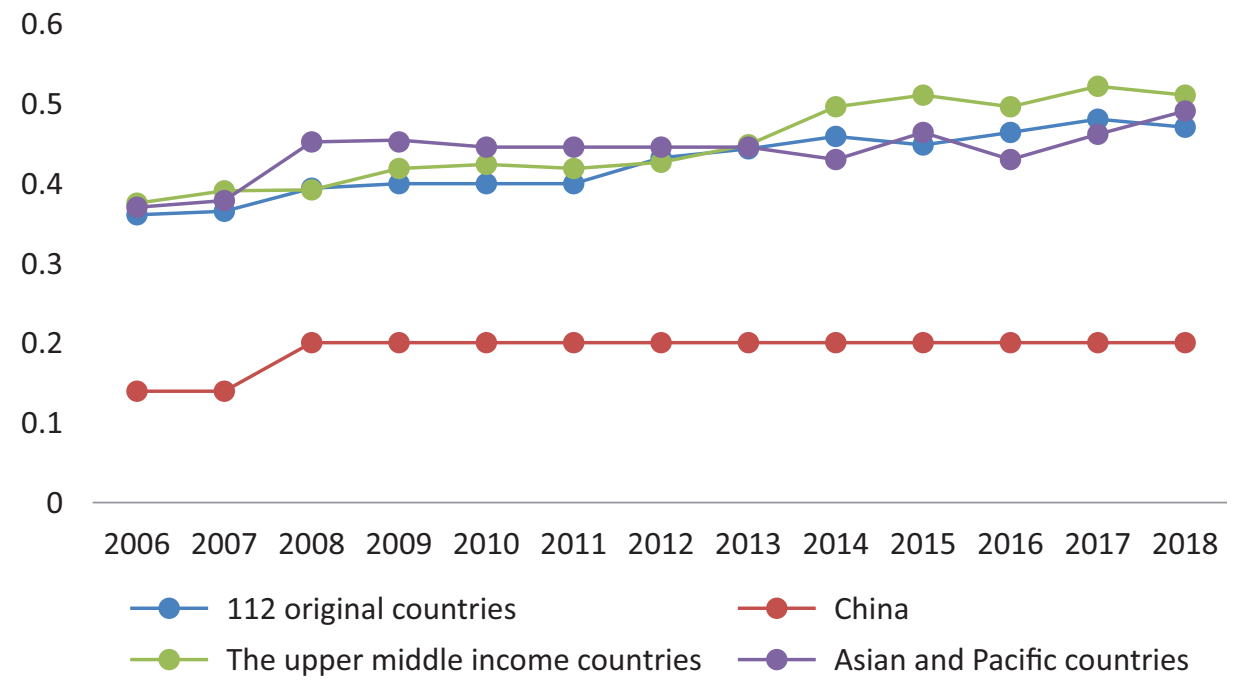

Figure 4. Trend comparison of scores on legislators and senior officials. Source: WEF (2006, 2008-2018).

2013). According to Li and Li (2008), gender discrimination in China's labor market since the economic transformation is likely to have shifted from the form of 'same work with different pay' to a more implicit allocative discrimination and to occupational segregation. Wu \& Wu (2009) found that gender segregation of industrial occupations was the main determinant of the gender income gap among urban workers in China. Also, within the same industry, women are heavily concentrated at the bottom of the job 'pyramid' structure such that $41 \%$ of the gender income gap is caused by occupation segregation (Qing \& Zheng, 2013). Thus, these two forms of segregation explain the widening gender gap in income in China's labor market, phenomena that have also been shown to explain most of the earning disparities between men and women in other countries (Cohen \& Huffman, 2003; Petersen \& Morgan, 1995).

\subsection{Educational Attainment}

China's educational gender gap resembles 'spindles,' that is, the gaps in higher education and primary education are relatively small, while those in secondary education are slightly larger. From 2006 to 2018, the biggest improvement in the gender gap was in higher education, with an increase in the index from 0.85 in 2006 to 1.00 in 2018, indicating that, in terms of enrollment rate, China's higher education has achieved gender equality. This is consistent with the education statistics issued by the China's Ministry of Education. From 2006 to 2018, the number of general full-time college students in Higher Education in China increased from 17,388,441 to 28,310,348 (Ministry of Education of the People's Republic of China, 2006a, 2018a), a 2.63 times increase. The proportion of full-time college students who are women increased from $48.1 \%$ in 2006 to $52.5 \%$ in 2018 . Primary education also achieves gender equality with the popularization of universal introduction of compulsory education. Based on the $1 \%$ sample survey data of China in 2005, Fang (2009) found that with universal compulsory education, the gender gap in primary education in China had almost disappeared. The development of economy, the process of industrialization, subreplacement fertility caused by family planning policy, and the strong promotion of the Chinese government have all contributed to the achievement of primary and tertiary education.

It is the gender gap in secondary education enrollment rate that has led to China's overall score and ranking in the field of education lagging behind that of other countries. It can be seen from GGGR data that during this period, this score fell from 0.97 to 0.941 and the ranking from 81 in 2006 to 130 out of 149 countries (102 among the original 112 countries) in 2018. The corresponding change during the same period was positive in most other countries; for the 112 original countries it was $0.034(3.6 \%)$, for upper-middle income countries it was $0.008(0.8 \%)$, and for Asian and the Pacific countries it was 0.018 (1.9\%). Due to lack of data on the secondary education in China from 2013-2015, GGGR reports that the gender gap remained largely stable, gradually increasing after 2016 (as shown in Figure 5). This change was basically in line with the increase in female enrollment in upper secondary education based on the annual education statistics provided by the website of China's Ministry of Education, as shown in Figure 6.

While the ratio of girls to boys enrolled in secondary education fell, the proportion of girls in regular senior high schools increased year by year, from $46.8 \%$ in 2006 to $50.8 \%$ in 2018 (Figure 6). The gender structure in secondary education reflects the high sex ratio at birth, since there is no strong evidence to suggest that it resulted from a boy preference in terms of the admission to secondary education. On one hand, the admission to high school requires passing a rigorous selective examination, which largely ensures decisions on students' admission to high school are not influenced by gender preference. The continuous proportion of regular senior secondary 


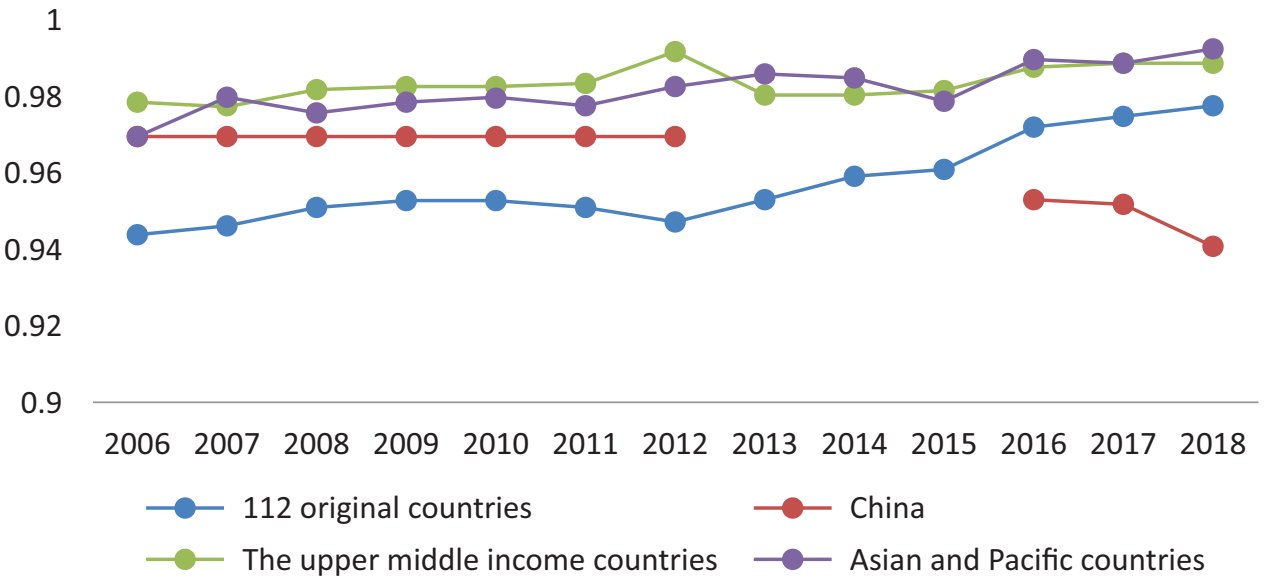

Figure 5. Trend comparison of scores on enrolment in secondary education. Source: WEF (2006, 2008-2018).

school pupils who are girls reflects the improvement in girls' educational performance which has exceeded that of boys since 2015 (Figure 6). Moreover, regular senior secondary schooling is preferred by students and parents as it is the major channel for students to enter higher education. The competition to access to regular senior secondary schooling is therefore more severe than that to enter secondary vocational education. On the other hand, the lower threshold for entry to secondary vocational schools means that there is no obvious obstacle preventing girls from accessing secondary vocational schools, therefore strongly suggesting that girls choose to give up vocational education, preferring senior high schools. Therefore, in the GGGR report, taking the gender gap in enrollment into the whole secondary education as the only indicator to measure the gender inequality in secondary education is inappropriate in the Chinese case.

Finally, the literacy rate reflects the country's long run ability to educate women and men in equal numbers. China's score was higher than the average level in 2018.
Moreover, during the period from 2006 to 2018, this indicator for China rose faster $(0.041 ; 4.5 \%)$ than that for the 112 original countries $(0.020)$, the upper-middle income countries (0.020), and the Asian and the Pacific countries (0.024). Even so, China's rank dropped from 81 place in 2006 to 94 out of 149 countries in 2018 (ranking 81 out of 112 original countries).

\subsection{Health and Survival}

According to the GGGR, China's performance with respect to the health and survival indicators, as shown in Table 4, falls far short of the world average. This is especially so for the sex ratio at birth, which measures the phenomenon of 'missing women' prevalent in many countries with strong son preference. The sex ratio for China was the second lowest in 2006 and the last of 149 countries in 2018.

The sex ratio at birth is a basic indicator reflecting the gender equality at birth. Shi (2013) reports that China's

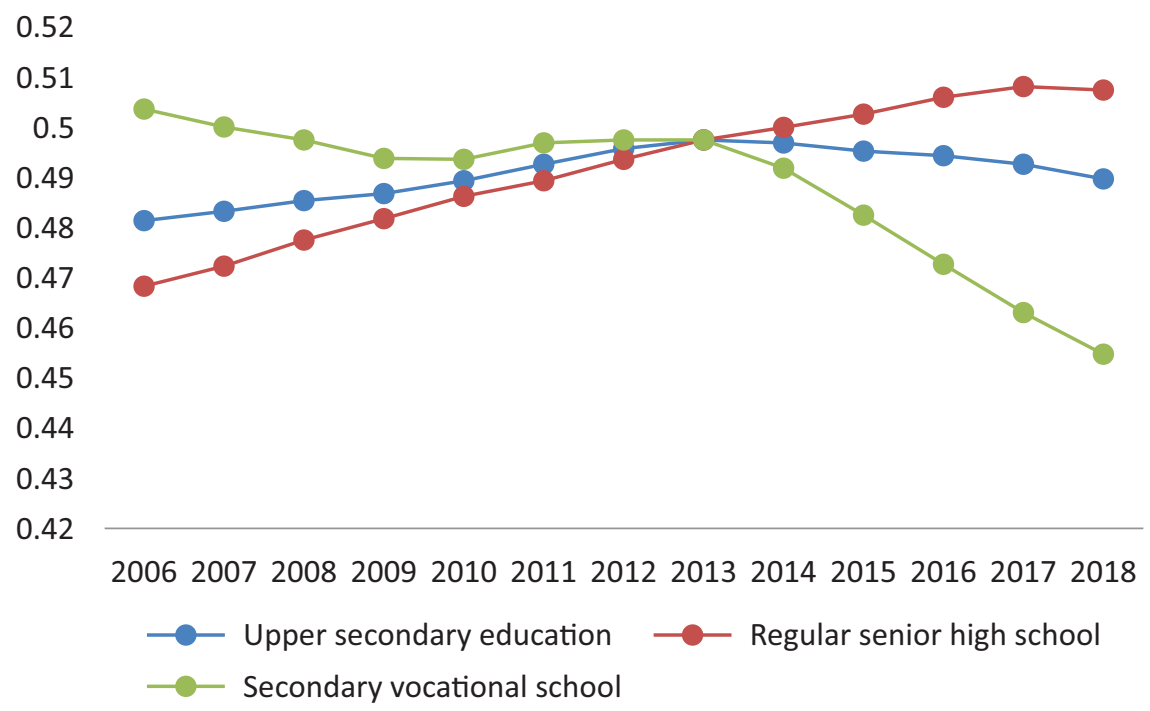

Figure 6. Female percentage of enrollment in upper secondary education. Source: Ministry of Education of the People's Republic of China (2006b, 2007-2017, 2018b). 
Table 4. Comparison of the scores on health and survival and political empowerment.

\begin{tabular}{|c|c|c|c|c|c|}
\hline & & 2006 & 2018 & Change & Rate of change (\%) \\
\hline \multirow[t]{4}{*}{ Sex ratio at birth } & China & 0.89 & 0.87 & -0.02 & -2.2 \\
\hline & The 112 original countries & 0.938 & 0.942 & 0.004 & 0.4 \\
\hline & The upper-middle income countries & 0.933 & 0.940 & 0.007 & 0.7 \\
\hline & Asian and the Pacific countries & 0.933 & 0.936 & 0.003 & 0.3 \\
\hline \multirow[t]{4}{*}{ Healthy life expectancy } & China & 1.03 & 1.019 & -0.011 & -1.1 \\
\hline & The 112 original countries & 1.044 & 1.043 & -0.001 & -0.0 \\
\hline & The upper-middle income countries & 1.051 & 1.052 & 0.001 & 0.1 \\
\hline & Asian and the Pacific countries & 1.049 & 1.046 & -0.003 & -0.3 \\
\hline \multirow[t]{4}{*}{ Women in parliament } & China & 0.25 & 0.332 & 0.082 & 32.8 \\
\hline & The 112 original countries & 0.217 & 0.346 & 0.129 & 59.4 \\
\hline & The upper-middle income countries & 0.229 & 0.375 & 0.146 & 63.8 \\
\hline & Asian and the Pacific countries & 0.191 & 0.276 & 0.085 & 44.5 \\
\hline \multirow[t]{4}{*}{ Women in ministerial positions } & China & 0.07 & 0.111 & 0.041 & 58.6 \\
\hline & The 112 original countries & 0.211 & 0.306 & 0.095 & 45.0 \\
\hline & The upper-middle income countries & 0.197 & 0.300 & 0.103 & 52.3 \\
\hline & Asian and the Pacific countries & 0.133 & 0.209 & 0.076 & 57.1 \\
\hline \multirow{4}{*}{$\begin{array}{l}\text { Years with female head of state } \\
\text { (last 50) }\end{array}$} & China & 0.03 & 0.076 & 0.046 & 153 \\
\hline & The 112 original countries & 0.044 & 0.081 & 0.037 & 84.1 \\
\hline & The upper-middle income countries & 0.009 & 0.035 & 0.026 & 289 \\
\hline & Asian and the Pacific countries & 0.053 & 0.096 & 0.043 & 81.1 \\
\hline
\end{tabular}

high sex ratio at birth is prevalent nationwide, and Shi and Liu (2015) found that it increased between the 1990s and 2010. The imbalance of sex ratio at birth is the result of the joint effect of male preference and fertility policy. In response to the trend towards an aging population, the Chinese government, from 2013 to 2015, began to adjust the strict family planning policy and successively introduced a revised 'one-child policy' and 'universal two-child policy.' These policies are likely to reduce the scope for gender selection in urban families, and thus make it possible for China's sex ratio at birth to decrease. However, the GGGR data suggest that, against inspections, the sex ratio at birth worsened after 2014.

The other indicator used by GGGR to measure the difference of the health status by gender is active life expectancy. According to the data from GGGR, the gender gap in China was relatively large, and further expanded between 2006 and 2018. In 2006, China's score was 1.03, lower than the average of the original 112 countries and the upper-middle income countries. China's rank position fell from 87 in 2006 to 132 out of 149 countries in 2018, ranking 100 out of the original 112 countries in 2018, having dropped 12 places. It is clear, therefore, that active life expectancy contributed to China's decline on the overall GGGR Index (Figure 7).

There are limitations to using the healthy life expectancy and the sex ratio at birth as crucial indicators for gender gap index of health and survival. Since women's healthy life expectancy is higher than men's in almost all countries (except Kuwait, Bhutan, and Bahrain), the value of this indicator is questionable, both theoretically and in practice. Also, since the sex ratio at birth is assigned a weight of 0.693 when calculating the index of health and survival, all countries with high sex ratios at birth are likely to rate low on the health and survival index (such as Armenia, Azerbaijan, India, Vietnam, among others; Zheng, 2019). China therefore rates poorly on the heath and survival index largely because of its score on sex imbalance at birth. It is easily visible that the sex ratio at birth is heavily weighted and plays an pivotal role in the index of the health and survival and so China (and some other countries), which has(have) been at the lowest level in the sex ratio at birth, tend to score poorly in the health and survival index overall.

\subsection{Political Empowerment}

The GGGR uses three indicators to measure political empowerment gap between men and women in decisionmaking at the highest level that is women in parliament, women in ministerial positions, and the ratio of women to men in terms of years in executive office (prime minister or president) over the last 50 years. While all three indicators of political empowerment show a certain improvement for China, for two of the three indicators it was less than either. The growth rate of these two indicators in China was lower than the world average or that for upper-middle income countries between 2006 and 2018 (see Table 4). The exception was the index of the female head of state (last 50).

China differs little from other countries in terms of the number of women in Parliament, although between 


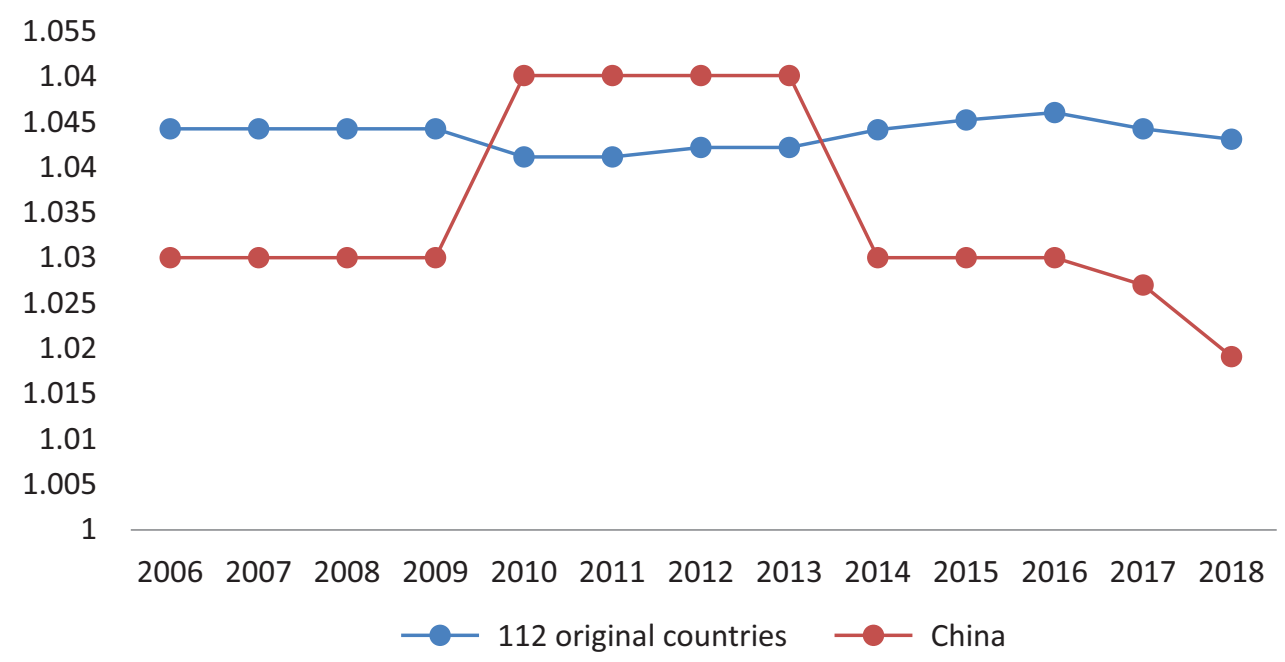

Figure 7. Time series comparison of gender gap index in healthy life expectancy. Source: WEF (2006, 2008-2018).

2006 and 2018 it slipped from above to below average and relative progress has been particularly poor since 2014 (Figure 8). In terms of women in ministerial positions, China is much below average, and behind countries with an equivalent level of development (Figure 9). Even in the best year, 2012, China's score was only $48.9 \%$ of the average; in 2018, the corresponding figure was just $36.6 \%$.

It has been argued that the GGGR embodies an elite bias in the selection of female political empowerment indicators (Yang, 2018) and that the indicators are too narrowly focused on the highest level. In China, the ratio of women's participation is higher in local politics than it is at parliamentary and ministerial levels. According to the Seventh and Eighth Periodic Report Reports submitted by China under Article 18 of the Convention on the Elimination of All Forms of Discrimination against Women (Committee on the Elimination of Discrimination against Women [CEDAW], 2012), women accounted for $11.0 \%$ and $13.7 \%$ at the provincial and 291 prefecture (director-general) levels. Above the county level, women held $16.4 \%$ of positions in 2009.
In the same year, not over a decade ago, $90.3 \%$ of provinces, $89.5 \%$ of municipalities, and $88.4 \%$ of counties had women within their leadership teams (Figure 10; as seen in CEDAW, 2012). It shows an increasing trend of the rate on female participation in local politics.

Article 6 of Election Law of the People's Republic of China for the National People's Congress and Local People's Congresses at All Levels (Standing Committee of the National People's Congress, 2015) states that the National People's Congress and local people's congresses at all levels should have an appropriate number of women's representatives, and should continue to gradually increase the proportion of women's representatives. In the past decade, the Chinese Government has adopted a number of strategies to promote the participation of women in all levels of management and decision-making. The National Human Rights Action Plan for 2009-2010 set a specific target regarding the proportion of women in politics, i.e., "people's congresses, political consultative conferences and local governments at all levels should have at least one female member in their leadership" (Information Office of the

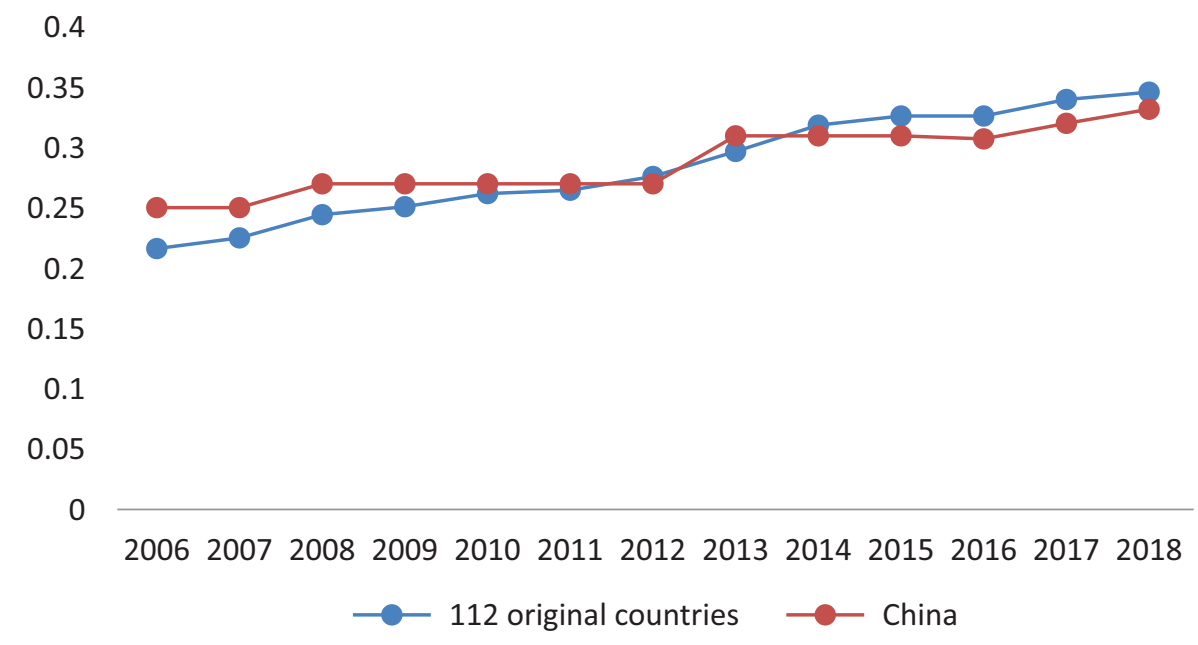

Figure 8. Time series comparison of index in women in parliament. Source: WEF (2006, 2008-2018). 


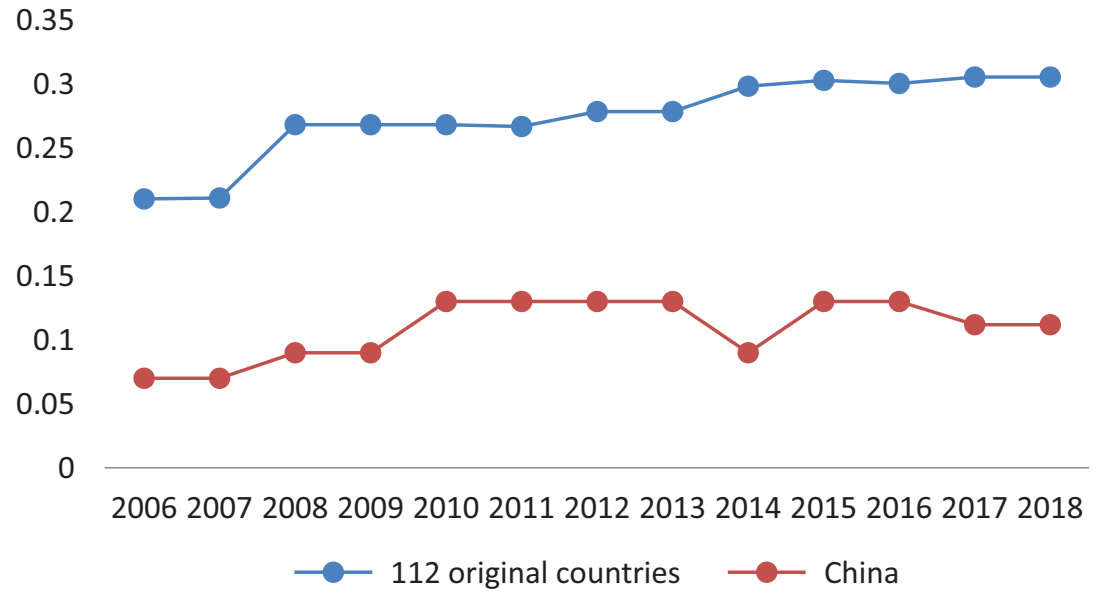

Figure 9. Time series comparison of index in women in in ministerial positions. Source: WEF (2006, 2008-2018).

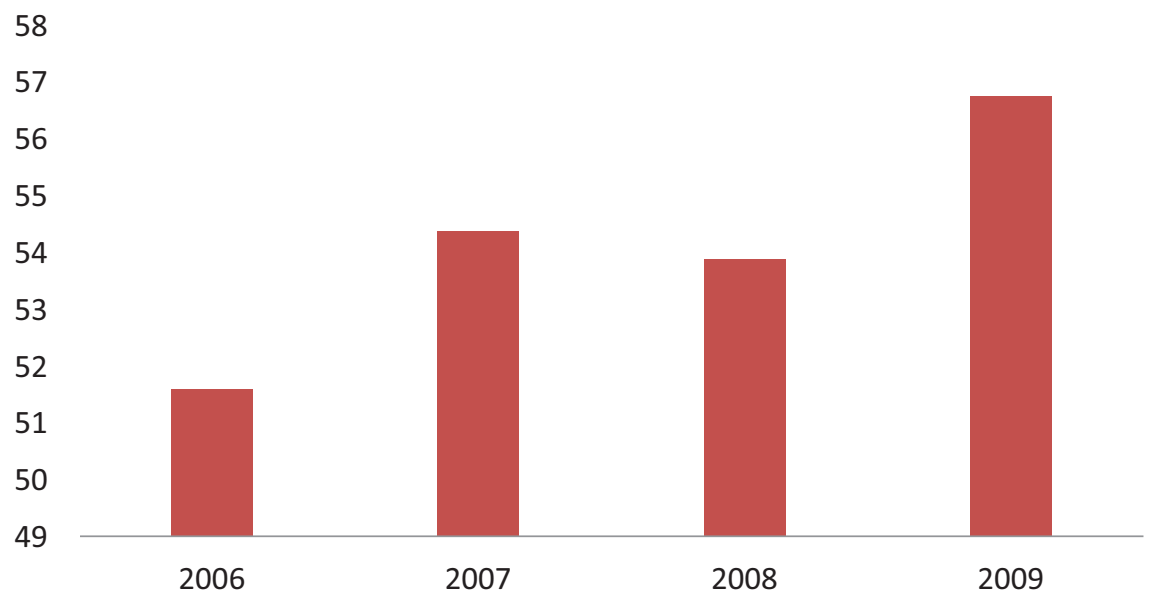

Figure 10. Percentage of leading bodies of government departments at the provincial level that had female cadres. Source: CEDAW (2012).

State Council, 2009). Thereafter, National Human Rights Action Plan for 2016-2020 stated that the proportion of women among the people's congress representatives and Chinese People's Political Consultative Conference members at all levels should be gradually increased (Information Office of the State Council, 2016).

However, the extent to which these strategies are being actively pursued and the legislation enforced is open to debate. Considering the proportion of women in the population versus the role they play in China's economy and society, Chinese women's participation in political empowerment remains a challenge. The overall proportion of women in politics is obviously low, and there are more women who are deputies than chiefs, particularly in Party committees and governments at the city and county levels. It is suggested that the civil and political environment for women's participation needs further improvement.

\section{Discussion and Conclusion}

To conclude, China's fall in rank position is not only related to a slower than average improvement, but also to the choice of indicators. In addition, there has been an expansion in the sample of countries with the majority of additional countries having higher scores than China. Having witnessed a relative improvement from 2006 to 2013, when China had a score that was 2.9\% above the international average (114 countries) which was due largely to a marked increase in score between 2006 and 2009, China has subsequently fallen behind other countries, most notably between 2013 and 2014 .

Like other countries, the gender gap was relatively smaller in the fields of education and health, but between 2006 and 2018, China's improvement in these two fields was relatively slow or even stagnant. First, China's high sex ratio at birth and the further expansion of gender gap in active life expectancy caused China's overall score and ranking to slip. It can be expected that with the adjustment of China's family planning policy, the high sex ratio at birth in China will fall. Second, the widening gender gap in secondary education is another important factor influencing the overall score. However, the current indicators are too crude to reflect the actual gender stratification. The distinction between regular high school and vocational education is missed and with it evidence that 
girls, who are increasingly performing better than boys, are choosing to attend higher status high school rather than vocational education. Gender gap on the enrollment in secondary education is influenced by the high sex ratio at birth, which amounts to double counting.

The gender gap in China's economic participation and political empowerment continues to narrow, but generally speaking, the improvement is far lower than the world average and for countries of a similar level of development. Although there is a system of equal pay for equal work and a high level of female labor participation, the income gap remains and even further expands. One possible reason is that China is still a patriarchal society with men holding a lot of distributive resource, thereby creating greater obstacles that inhibit women from progressing in high-income industries and serving in highincome occupations.

Investigating the reasons for China's fall in rank position by examining through the score changes of subdimensions and indicators, some scholars have queried the rationality of the choice of GGGR indicators. The following issues have been identified: First, there is concern about the selection of indicators and their appropriateness. As stated above, the life expectancy of women is globally higher than that of men in almost all countries, while the ratios of health and survival (91-98\%) have been fairly stable since 2006 suggesting a lack the sensitivity (Zheng, 2019). A major difference between the GGGR and the GII which was developed by the United Nations Development Programme (2019), and on which China ranked 39 out of 189 countries in 2018 rather than 113 out of 149 , lies in the selection of health indicators. The GII employs the maternal mortality ratio and the adolescent birth rate to measure gender inequality in health, rather than the sex ratio at birth and healthy life expectancy. The GII and the GGGR differ little with respect to indicators of education, labor market participation, and political empowerment, pointing to the importance of the measures of health inequality in explaining the difference in rank order, and Zheng (2019) makes the case that the indicators of health inequality adopted by the GII are to be preferred. It can be argued that other indicators are not well suited to circumstances in China. For instance, the three indicators used by GGGR to measure political empowerment only reflect the highest levels, while measure of enrollment in secondary education confound high school and vocational education. Second, there is concern about the substitution for absent data and out of data lag, which may affect the accuracy of the indicator and its results. For example, the substitute indicator for the enrollment rate of secondary education adopted by GGGR (2018) is the percentage of female students in secondary education: $47.1 \%$ girls. Considering that the indicator of the percentage of female students in secondary education reflects the continuing influence of high sex ratio at birth, this formulation may not necessarily measure the gender inequality of accessibility in secondary education.
In summary, despite concerns about the selection of some indicators and data sources, the GGGR of the WEF provides a significant reference for China to analyze and track its gender gap. The slow improvement of China's gender equality only emphasizes the need for a joint effort on behalf of the government and the whole society. Gender inequality is not only deeply embedded in a country's politics, economy, education and health, but also influenced by culture, social norms, patriarchy, and the distribution of power and authority.

\section{Acknowledgments}

This article could not have been written without the invaluable encouragement and assistance of Robert Walker who has input at various stages throughout the writing and revision process. We are grateful to Jane Millar for her assistance with revisions to the manuscript. We also would like to acknowledge the work of reviewers who provided insights and suggestions. We would like to thank the support and expertise of Cogitatio, in particular, Mariana Pires.

\section{Conflict of Interests}

The authors declare no conflict of interests.

\section{References}

Anker, R. (1997). Theories of occupational segregation by sex: An overview. International Labour Review, 136(3), 315-339.

Cohen, P. N., \& Huffman, M. L. (2003). Occupational segregation and the devaluation of women's work across U.S. labor markets. Social Forces, 81(3), 881-908.

Committee on the Elimination of Discrimination against Women. (2012). Consideration of reports submitted by states parties under Article 18 of the convention on the elimination of all forms of discrimination against women: Combined seventh and eighth periodic report of states parties-China (CEDAW/C/CHN/7-8). Geneva: Office of the United Nations High Commissioner for Human Rights. Retrieved from https://tbinternet.ohchr.org/_layouts/ 15/treatybodyexternal/Download.aspx?symbolno= CEDAW\%2fC\%2fCHN\%2f7-8\&Lang=en

Deng, F., \& Ding, X. H. (2012). Human capital, labor market segmentation and gender income gap. Sociological Study, 5, 29-51.

Fang, C. C. (2009). Gender differences in the development of reduction as shown by gender parity index. Society, 1, 19-25.

He, G. Y., \& Wu, X. G. (2017). Marketization, occupational segregation, and gender earnings inequality in urban China. Social Science Research, 65, 96-111.

Information Office of the State Council. (2009). National human rights action plan of the People's Republic of China. Beijing: State Council of China. 
Information Office of the State Council. (2016). National human rights action plan of the People's Republic of China. Beijing: State Council of China.

Li, C. L., \& Li, S. (2008). Rising gender income gap and its dynamics in China: Market competition or sex discrimination? Sociological Study, 2, 94-117.

Ministry of Education of the People's Republic of China. (2006a). Number of students in regular HEls by field of study from the educational statistics in 2006. Ministry of Education of the People's Republic of China. Retrieved from http://www.moe.gov.cn/ s78/A03/moe_560/moe_1659/moe_1661/201002/ t20100226_27272.html

Ministry of Education of the People's Republic of China. (2006b). Number of secondary vocational schools and regular high school enrollment from the educational statistics in 2006. Ministry of Education of the People's Republic of China. Retrieved from http:// www.moe.gov.cn/s78/A03/moe_560/moe_1659

Ministry of Education of the People's Republic of China. (2007). Number of secondary vocational schools and regular high school enrollment from the educational statistics in 2007. Ministry of Education of the People's Republic of China. Retrieved from http://www. moe.gov.cn/s78/A03/moe_560/moe_2896

Ministry of Education of the People's Republic of China. (2008). Number of secondary vocational schools and regular high school enrollment from the educational statistics in 2008. Ministry of Education of the People's Republic of China. Retrieved from http://www. moe.gov.cn/s78/A03/moe_560/s4628/

Ministry of Education of the People's Republic of China. (2009). Number of secondary vocational schools and regular high school enrollment from the educational statistics in 2009. Ministry of Education of the People's Republic of China. Retrieved from http://www. moe.gov.cn/s78/A03/moe_560/s4958/

Ministry of Education of the People's Republic of China. (2010). Number of secondary vocational schools and regular high school enrollment from the educational statistics in 2010. Ministry of Education of the People's Republic of China. Retrieved from http://www. moe.gov.cn/s78/A03/moe_560/s6200

Ministry of Education of the People's Republic of China. (2011). Number of secondary vocational schools and regular high school enrollment from the educational statistics in 2011. Ministry of Education of the People's Republic of China. Retrieved from http://www. moe.gov.cn/s78/A03/moe_560/s7382/

Ministry of Education of the People's Republic of China. (2012). Number of secondary vocational schools and regular high school enrollment from the educational statistics in 2012. Ministry of Education of the People's Republic of China. Retrieved from http://www. moe.gov.cn/s78/A03/moe_560/s7567/

Ministry of Education of the People's Republic of China. (2013). Number of secondary vocational schools and regular high school enrollment from the educational statistics in 2013. Ministry of Education of the People's Republic of China. Retrieved from http://www. moe.gov.cn/s78/A03/moe_560/s8492

Ministry of Education of the People's Republic of China. (2014). Number of secondary vocational schools and regular high school enrollment from the educational statistics in 2014. Ministry of Education of the People's Republic of China. Retrieved from http://www. moe.gov.cn/s78/A03/moe_560/jytjsj_2014

Ministry of Education of the People's Republic of China. (2015). Number of secondary vocational schools and regular high school enrollment from the educational statistics in 2015. Ministry of Education of the People's Republic of China. Retrieved from http://www. moe.gov.cn/s78/A03/moe_560/jytjsj_2015

Ministry of Education of the People's Republic of China. (2016). Number of secondary vocational schools and regular high school enrollment from the educational statistics in 2016. Ministry of Education of the People's Republic of China. Retrieved from http://www. moe.gov.cn/s78/A03/moe_560/jytjsj_2016

Ministry of Education of the People's Republic of China. (2017). Number of secondary vocational schools and regular high school enrollment from the educational statistics in 2017. Ministry of Education of the People's Republic of China. Retrieved from http://www. moe.gov.cn/s78/A03/moe_560/jytjsj_2017

Ministry of Education of the People's Republic of China. (2018a). Number of undergraduate students by type of courses in regular HEls from the educational statistics in 2018. Ministry of Education of the People's Republic of China. Retrieved from http://www.moe.gov.cn/s78/A03/moe_560/jytjsj_ 2018/qg/201908/t20190812_394195.html

Ministry of Education of the People's Republic of China. (2018b). Number of secondary vocational schools and regular high school enrollment from the educational statistics in 2018. Ministry of Education of the People's Republic of China. Retrieved from http:// www.moe.gov.cn/s78/A03/moe_560/jytjsj_2018/

Petersen, T., \& Morgan, L. A. (1995). Separate and unequal: Occupation-establishment sex segregation and the gender wage gap. American Journal of Sociology, 101(2), 329-365.

Qing, S. S., \& Zheng, J. M. (2013). Unequal pay or unequal job: Effect of hierarchical segregation on gender earning differentials. China Economic Quarterly, 12(2), 367-388.

Shi, M. Y., \& Liu, S. (2015). Sex ratio at birth in China: Changes and implications. Population Research, 39(4), 35-48.

Shi, R. B. (2013). Changing patterns of sex ratio at birth in China: A comparative analysis of data from the firth and sixed censuses of China. Population Research, $37(2), 66-72$.

Standing Committee of the National People's Congress. (2015). Election law of the People's Republic of China for the National People's Congress and Local People's 
congresses at all levels (Order No. 33 of the President of the People's Republic of China). Beijing: Standing Committee of the National People's Congress.

Tang, M. J. (2019, January 7). A correct understanding of the global gender gap assessment index. China Population News. Retrieved from http://kns.cnki.net/ $\mathrm{kcms} /$ detail/detail.aspx?dbcode=CCND\&filename $=$ CRCB201901070031\&dbname=CCNDLAST2019

Tong, M., \& Wang, H. B. (2013). Market transition and vertical occupational gender segregation. Society, 33(6), 129-145.

United Nations Development Programme. (2019). Human development report 2019. Beyond income, beyond averages, beyond today: Inequalities in human development in the 21st century. New York, NY: United Nations Development Programme. Retrieved from http://hdr.undp.org/en/2019-report

World Economic Forum. (2006). The global gender gap report 2006. Cologny: World Economic Forum. Retrieved from https://www.weforum.org/reports/ global-gender-gap-report-2006

World Economic Forum. (2008). The global gender gap report 2008. Cologny: World Economic Forum. Retrieved from https://www.weforum.org/reports/ global-gender-gap-report-2008

World Economic Forum. (2009). The global gender gap report 2009. Cologny: World Economic Forum. Retrieved from https://www.weforum.org/reports/ global-gender-gap-report-2009

World Economic Forum. (2010). The global gender gap report 2010. Cologny: World Economic Forum. Retrieved from https://www.weforum.org/reports/ global-gender-gap-report-2010

World Economic Forum. (2011). The global gender gap report 2011. Cologny: World Economic Forum. Retrieved from http://reports.weforum.org/globalgender-gap-2011

World Economic Forum. (2012). The global gender gap report 2012. Cologny: World Economic Forum. Retrieved from https://www.weforum.org/reports/ global-gender-gap-report-2012

World Economic Forum. (2013). The global gender gap report 2013. Cologny: World Economic Forum. Retrieved from https://www.weforum.org/reports/ global-gender-gap-report-2013

World Economic Forum. (2014). The global gender gap report 2014. Cologny: World Economic Forum. Retrieved from https://www.weforum.org/reports/ global-gender-gap-report-2014

World Economic Forum. (2015). The global gender gap report 2015. Cologny: World Economic Forum. Retrieved from hhttps://www.weforum.org/reports/ global-gender-gap-report-2015

World Economic Forum. (2016). The global gender gap report 2016. Cologny: World Economic Forum. Retrieved from https://www.weforum.org/reports/ the-global-gender-gap-report-2016

World Economic Forum. (2017). The global gender gap report 2017. Cologny: World Economic Forum. Retrieved from https://www.weforum.org/reports/ the-global-gender-gap-report-2017

World Economic Forum. (2018). The global gender gap report 2018. Cologny: World Economic Forum. Retrieved from https://www.weforum.org/reports/ the-global-gender-gap-report-2018

Wu, Y. X., \& Wu, X. G. (2009). Occupational gender segregation and gender wage gap in urban China. Sociological Studies, 4, 88-111.

Yang, J. H. (2018). International comparison of theories and methodologies on gender equality evaluation: A case study of the global gender gap report. Women's Commission of Xiamen University. Retrieved from https://women.xmu.edu.cn/2018/ 1225/c1514a360265/page.htm

Zheng, Z. Z. (2019). Rethinking the theory and method of gender equality assessment: Taking health and survival index as an example. China Development Brief. Retrieved from http://www.chinadevelopmentbrief. org

\section{About the Authors}

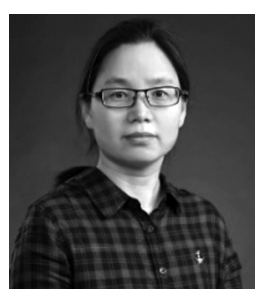

Binli Chen is Assistant Professor in the School of Social Development and Public Policy at Beijing Normal University. Her research fields are sociology of education, children studies, and gender stratification in education. She is currently working on the topics of parenting values and practices of middle class and migrant workers in urban China.

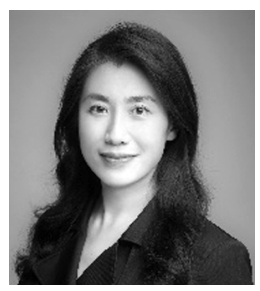

Hailan He is Assistant Professor at National Collaborative Innovation Center of Assessment for Basic Education Quality, Beijing Normal University. She holds a LL.M from Utrecht University (2008) and a PhD from China's University of Political Science and Law (2012). Her recent research includes children's rights, women's rights, right to breastfeeding, educational law, and policies. She is author of The Principle of The Best Interest of The Child: Implementation in Education, Family and Criminal Institutions (China Legal Publishing House, 2016) and co-author and co-editor of The Knowledge of Human Rights: A Context Book for Judges (Hunan University Publishing House, 2012). 